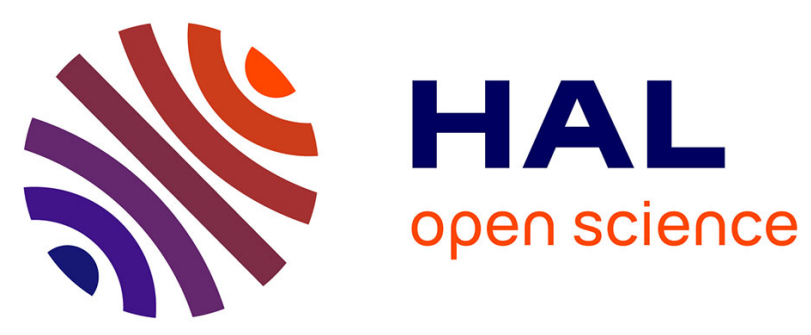

\title{
Evidentials in Pingwu Baima
}

\author{
Katia Chirkova
}

\section{To cite this version:}

Katia Chirkova. Evidentials in Pingwu Baima. Evidential Systems of Tibetan Languages, ed. par Lauren Gawne et Nathan W. Hill, De Gruyter Mouton, pp.445-459, 2017, Evidential Systems of Tibetan Languages, 978-3-11-046018-6. hal-01485399

\section{HAL Id: hal-01485399 \\ https://hal.science/hal-01485399}

Submitted on 8 Mar 2017

HAL is a multi-disciplinary open access archive for the deposit and dissemination of scientific research documents, whether they are published or not. The documents may come from teaching and research institutions in France or abroad, or from public or private research centers.
L'archive ouverte pluridisciplinaire HAL, est destinée au dépôt et à la diffusion de documents scientifiques de niveau recherche, publiés ou non, émanant des établissements d'enseignement et de recherche français ou étrangers, des laboratoires publics ou privés. 


\title{
Evidentials in Pingwu Baima*
}

Katia Chirkova

CNRS-CRLAO

\begin{abstract}
This article provides a descriptive overview of the system of evidentiality in Baima, a Tibetic language spoken at the border of Sichuan and Gansu Provinces, China. The overview is based on first-hand fieldwork data on the variety of Baima as spoken in Pingwu County, Sichuan. It relies on elicited verb paradigms and verb forms occurring in a corpus of traditional stories. The Pingwu Baima evidentiality system is shown to be fairly unique in the Tibetic context in its lexical choices and etymological origins. It is argued to combine features generally found in the Central and Khams varieties (such as a separate egophoric receptive marker) with some unusual developments so far only attested in some Tibetic languages spoken in the border areas between Sichuan and Gansu (the homophony between the indirect evidential and the indefinite marker).
\end{abstract}

\section{Introduction}

Baima is a Tibetic language, spoken by approximately 10,000 people in three counties in Sichuan Province (Pingwu 平武, Songpan 松潘, Jiuzhaigou 九寨沟) and one county in Gansu Province (Wenxian 文县) in the People's Republic of China. The Baima people call themselves $/ \mathrm{pe}^{53} /$ bod and they are known under the name of Dwags-po in Tibetan. In Pingwu, Songpan, and Jiuzhaigou, they reside in close proximity with Tibetan and Han Chinese groups, whereas in Wenxian, Han Chinese are the Baima's only neighbouring ethnic group. Baima is considered a distinct language by its speakers and it is not mutually intelligible with the Tibetic varieties in its neighborhood.

Baima is little-studied. Linguistic accounts to date have essentially focused on the disputed status of Baima as either a Tibetic language (or a dialect of Tibetan in the Chinese linguistic scholarship) (Zhang 1994a, 1994b, 1997; Huang and Zhang 1995) or a Bodic

\footnotetext{
* This article builds on my earlier work on Baima evidentials (Chirkova 2008a). I would like to thank Ulatus for preparing an English translation of the original article under the auspices of the European Research Council funded project "Beyond Boundaries: Religion, Region, Language and the State" (ERC Synergy Project 609823 ASIA). Their translation was used as the basis for this study. I am grateful to M Li Degui for his help in checking and discussing the Baima examples cited in this paper.
} 
language distinct from Tibetan (H. Sun 1980a, 1980b, 2003; H. Sun et al. 2007; Nishida and Sun 1990). ${ }^{1}$

Baima is spoken in a multi-ethnic area, at the border of the historical provinces of Amdo and Khams of the Tibetan empire. This area is home to many language-like Tibetic varieties, such as Zhongu (J. Sun 2003a), Chos-rje (or Dpal-skyid) (J. Sun 2003b), Thebo (or Thewo) (Lin 2014), and Cone (or Chone) (Jacques 2014). In a recent classification of Tibetic languages by Nicolas Tournadre (2014: 121-123), these Tibetic varieties are grouped, together with Baima, into the Eastern section of the Tibetic family. Baima phonology and lexicon readily attest to the complex history of this language and to its intricate relationships with the neighboring Tibetic languages. Multiple sound correspondences between the phonological system of Baima and that of Old Tibetan, as reflected in standard Written Tibetan orthography (hereafter WT), suggest layers of loanwords from different Tibetic languages (Huang \& Zhang 1995: 91-92; Chirkova 2008b). To give an example, WT 'gr has two main reflexes in the basic lexicon of Baima: (1)/ndzl, as in $/$ ndz $^{35} /$ 'grang 'be full, be satiated with food', and (2) /ndz/, as in $/ \mathrm{nd} \mathrm{go}^{341} / \mathrm{g}$ 'gro 'walk'. Of these, the former

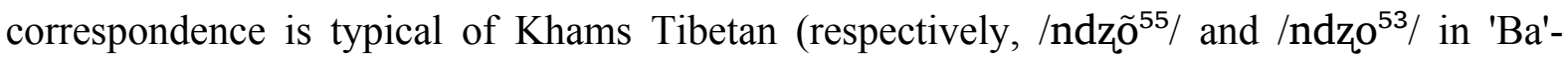
thang Tibetan, Huang et al. 1992: 605), whereas the second correspondence is characteristic of Amdo Tibetan (respectively, /dza / and /ndzo/ in bLa-brang Tibetan, Huang et al. 1992: 605). The linguistic influence of different donor languages is also detectable in Baima lexicon. For instance, Baima $/ \mathrm{ggs}^{241} \mathrm{na}^{53} \mathrm{ni}^{53} /$ 'human beings, mankind' is shared with Amdo

\footnotetext{
${ }^{1}$ Officially classified as Tibetans in the 1950s, the Baima advanced claims as an independent ethnic group in the 1960s and 1970s. The main arguments for an independent status included, on the one hand, linguistic differences between the Baima language and its neighboring Tibetic varieties and, on the other hand, major ethnographic differences between the Baima people and Tibetans. Baima generally adopted Chinese lifestyle and customs; they do not drink milk or use milk products, which are essential to the Tibetan diet; and they are not Buddhists, but practice indigenous animalist beliefs. In the 1970s, a group of PRC researchers conducted two surveys in the Baima areas and published two collections of papers, in which the Baima were claimed descendants of the ancient Di 氏 tribe, which set up influential kingdoms in the 3rd through the 6th centuries CE in the areas currently inhabited by the Baima. In the 7th century, the Di territories were occupied by Tibetans and the Di people are believed to have subsequently shifted to the form of Tibetan spoken by their invaders. Despite the conclusion that the Baima constitute a distinct ethnic group rather than a branch of Tibetans, they were never officially reclassified. See Chirkova $(2007,2008 \mathrm{c})$ for an account of the controversy surrounding the ethnicity of Baima Tibetans and their purported link to the Di group as documented in the Chinese historical records.
} 
mgo nag $m(y) i{ }^{2}$ while Baima $/ \mathrm{a}^{33} \mathrm{li}^{53} /$ 'cat' may probably be linked to $/ \mathrm{e}^{13} 1 \mathrm{e}^{53}$ in $\mathrm{Khams}$ Tibetan (as in Sde-dge) (Huang and Zhang 1995: 104). Much like its phonology and lexicon, the grammatical organization of Baima is characterized by a complex, multi-layered structure, as discussed in this article in relation to the system of evidentiality. The present overview is based on first-hand fieldwork data on the variety of Baima as spoken in Pingwu County, which has the largest concentration of Baima speakers throughout all Baima-speaking areas. This overview relies on elicited verb paradigms (used as main illustrative examples throughout the article) and verbs forms cited from traditional stories (used to address the issues of occurrence frequency and co-occurrence patterns of different markers of evidentiality with various types of verbs).

\section{Evidentials in Pingwu Baima: An overview}

Pingwu Baima has a hybrid evidentiality system that combines (a) specification of speaker's perspective towards the source of, and access to, information (egophoric vs. nonegophoric) and (b) specification of source of information (direct vs. indirect). The egophoricnon-egophoric distinction permeates the entire system, whereas the direct-indirect distinction is restricted to past time reference. ${ }^{3}$

The majority of Baima verbs have two stems: (1) non-past, corresponding to WT present and future stems, and (2) past, corresponding to WT past and imperative stems, as

\footnotetext{
${ }^{2}$ For more on the expression mgo nag myi, see Hill (2013), who discusses the use of this formula in Old Tibetan texts.

${ }^{3}$ Baima has no specialized marker of reported evidence. Reported speech is marked by the use of various forms of the default verb of speaking $/ \mathrm{dzo}^{341} /$. Consider the following examples:

$\mathrm{ni}^{53} \quad \mathrm{n}^{213} \quad \mathrm{dzo} \mathrm{d}^{341} \quad \mathrm{~d} \partial^{33}$.

person exist speak PROG

'There are reportedly people here.'

$\mathrm{k}^{\mathrm{h}} \mathrm{u}^{53} \quad \mathrm{gje}^{33} \mathrm{pu}^{53} \quad \mathrm{t} \varepsilon^{53} \quad \mathrm{ji}^{53}-\mathrm{e}^{53}-\mathrm{ndu}^{213} \quad \mathrm{u}^{33} \quad \mathrm{dz} \varepsilon^{35} \quad \mathrm{~S} \partial^{33}$. LOG old.man DEF eye-Q-see PFV.EGO.INT speak.PST PFV '[The demoness] said: "Have you seen my husband?",

Abbreviations

follow the Leipzig Glossing Rules (LGR, http://www.eva.mpg.de/lingua/resources/glossing-rules.php). Non-standard abbreviations (those not included in the LGR) are: $\mathrm{EGO}=$ egophoric, $\mathrm{EXP}=$ experiential, $\mathrm{INT}=$ intentional, $\mathrm{LOG}=$ logophoric, $\mathrm{PRSP}=$ prospective, $\mathrm{RCP}$ = receptive. The question mark sign (“?”) marks tentative WT glosses.
} 
illustrated in Table $1 .^{4}$ Non-past stems are mostly prenasalized and carry a falling tone (53/341), whereas past stems have a voiceless initial and carry the rising tone (35).

Table 1. Examples of past and non-past verb stems in Pingwu Baima

\begin{tabular}{|c|c|c|c|c|c|c|}
\hline \multicolumn{2}{|c|}{ Pingwu Baima } & \multicolumn{4}{|c|}{ Tibetan } & \multirow{2}{*}{ Meaning } \\
\hline Non-past & Past / Imperative & Present & Future & Past & Imperative & \\
\hline $\mathrm{ko}^{53}$ & $\mathrm{ku}^{35}$ & rko ba & brko & (b)rkos & rkos & dig \\
\hline $\mathrm{ndzo}^{341}$ & $\mathrm{ndzu}^{213}$ & 'tsho ba & gso & \multicolumn{2}{|c|}{ (b) $\operatorname{sos}$} & graze, herd \\
\hline $\mathrm{ndzu}^{341}$ & $\mathrm{tsu}^{35}$ & 'tshong & btsong & btsongs & tshong & sell \\
\hline $\mathrm{ta}^{53}$ & ty $^{35}$ & lta $b a$ & blta & bltas & ltos & look \\
\hline $\mathrm{mo}^{53}$ & $\mathrm{me}^{35}$ & \multicolumn{2}{|c|}{ rmo ba } & \multicolumn{2}{|c|}{ rmos } & plow, till \\
\hline ndza $^{341}$ & $\mathrm{tsse}^{35}$ & \multicolumn{2}{|c|}{$d r a b a$} & \multicolumn{2}{|r|}{ dras } & cut apart, sever \\
\hline$m b e^{53}$ & $\mathrm{pe}^{35}$ & \multicolumn{2}{|c|}{ 'bod pa } & \multicolumn{2}{|r|}{ bos } & call, shout \\
\hline $\mathrm{nj}^{53}$ & $\mathrm{ny}^{35}$ & \multicolumn{2}{|c|}{ nyo ba } & \multicolumn{2}{|r|}{ nyos } & buy \\
\hline
\end{tabular}

Evidential markers that combine with non-past verb stems form a simpler system with a binary opposition between egophoric and non-egophoric (or factual) forms. Evidential markers that are used with past verb stems, on the other hand, are more numerous and manifest a richer system of contrasts between egophoric, factual, direct, and indirect (inferred) evidential categories. An overview of all markers is provided in Table 2.

Table 2: Evidential markers in Pingwu Baima ${ }^{5}$

\footnotetext{
${ }^{4}$ A small number of (high frequency) verbs have three stems: in addition to the non-past and past stems, they also have a separate imperative stem. Verbs with three stems mostly use suppletive forms. Examples include: (1) 'walk, go': present/future: /ndzo ${ }^{53} /$ 'gro and $/ \mathrm{ndzi}^{53} / \mathrm{mchi}$, past $/ \mathrm{tc}^{\mathrm{h}} \mathcal{\varepsilon}^{35} /$ chas, imperative $/ \mathrm{s}^{\mathrm{h}} \mathrm{u}^{35} /$ song; (2) 'come': present/future / $\mathrm{wu}^{53} /$ 'ong, past / $\mathrm{ue}^{35 /}$ 'ongs and /6y $35 /$ byung, imperative /sue $53 /$ shog; (3) 'make': future/present $/ \mathrm{zo}^{341} /$ bzo ba, past $/ 6 \varepsilon^{35} /$ byas, imperative $/ \mathrm{t} 6 \mathrm{i}^{35} /$ gyis; (4) 'speak': future/present $/ \mathrm{dzo}^{341} / z^{3}$, past $/ \mathrm{dz \varepsilon}^{35} /$ bzlas, imperative /dzu ${ }^{213} /$ zlos. Finally, some verbs have only one stem, e.g. $/ \mathrm{k}^{\mathrm{h}} \mathrm{i}^{53} /$ 'lead, conduct, bring along', WT 'khrid pa, khrid; /nع $\varepsilon^{35} /$ 'sleep', WT nyal ba, nyol; /ts ${ }^{3}{ }^{35 /}$ 'look for', WT 'tshal/'tshol-ba, btsol, tshol.

${ }^{5}$ Baima does not have evidentiality distinction in the present progressive and uses one and the same progressive marker /də/ sdod? with all types of subjects and verbs. Compare the following examples: / $\mathrm{ga}^{35} \mathrm{so}^{35} \mathrm{ndu}^{35} \mathrm{da}^{33} /$

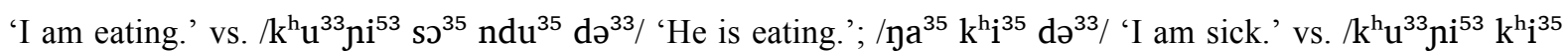
$\mathrm{d}^{33} /$ 'He is sick.'; / $/ \mathrm{n}^{35} \mathrm{mbu}^{53} \mathrm{~d}^{33} /$ 'It is raining.'

The majority of evidentials can occur in isolation and have etymological tones. Of those evidentials that do not occur in isolation, $/ \mathrm{i}^{53} /$ is consistently realized with the high falling tone, whereas $/ \mathrm{u}^{33} / \mathrm{and}^{3} / \mathrm{s}^{33} /$ are pronounced with a short, mid-pitch tone, notated here as "33" (neutral tone).
} 


\begin{tabular}{|c|c|c|c|c|c|}
\hline \multirow{2}{*}{\multicolumn{2}{|c|}{$\begin{array}{l}\text { Verb stem } \\
\text { Non-past }\end{array}$}} & \multicolumn{4}{|c|}{ Marker } \\
\hline & & \multicolumn{2}{|c|}{ Egophoric } & \multicolumn{2}{|c|}{ Non-egophoric (factual) } \\
\hline & Prospective & \multicolumn{2}{|c|}{$\mathrm{i}^{53}$ kyis $^{6}$} & \multicolumn{2}{|c|}{$\mathrm{re}^{213}$ red } \\
\hline & $\begin{array}{l}\text { Durative } \\
\text { (stative) }\end{array}$ & \multicolumn{2}{|c|}{$\mathrm{zy}^{341}$ yod } & \multicolumn{2}{|c|}{$\mathrm{n} \jmath^{213}$ snang } \\
\hline & Experiential & \multicolumn{2}{|c|}{$\mathrm{t} \int^{\mathrm{h}} \mathrm{a}^{53} \mathrm{zy}^{341}$ cha? yod } & \multicolumn{2}{|c|}{$\mathrm{t} \int^{\mathrm{h}} \mathrm{a}^{53} \mathrm{n}^{213}$ cha? snang } \\
\hline \multirow{2}{*}{\multicolumn{2}{|c|}{ Past }} & $\begin{array}{l}\text { Egophoric } \\
\text { intentional }\end{array}$ & $\begin{array}{l}\text { Egophoric } \\
\text { receptive } \\
\text { (centripetal) }\end{array}$ & $\begin{array}{c}\text { Direct } \\
\text { (centrifugal) }\end{array}$ & Indirect/Factual \\
\hline & & $\mathrm{u} \varepsilon^{33} ?$ & $6 \mathrm{y}^{35}$ byung & $\mathrm{t}^{\mathrm{h}} \varepsilon^{35}$ chas & sə $\partial^{33} ?$ \\
\hline
\end{tabular}

The basic organization of the system is as follows. Egophoric markers are prototypically used in the following two cases:

(i) with first person subjects in statements, in which the speaker is the willful instigator of a situation. Examples include:

(1)

\begin{tabular}{|c|c|c|c|c|}
\hline $\mathrm{ya}^{35} \quad \mathrm{nj}^{53}$ & $i^{53}$. & $\mathrm{ya}^{35}$ & ndzi ${ }^{53}$ & $i^{53}$. \\
\hline buy.N-PST & PRSP.EGO & $1 \mathrm{SG}$ & walk.N-PST & PRSP.EGO \\
\hline
\end{tabular}

(2)
$\mathrm{na}^{35} \mathrm{nc}^{35} \quad \mathrm{zy}^{341}$.
1SG sleep DUR.EGO
'I am sleeping.'

\footnotetext{
${ }^{6}$ The prospective egophoric marker $/ i^{53} /$ does not appear cognate to the egophoric equational copula yin in Standard Tibetan. According to regular correspondence rules, Pingwu Baima equivalent to $y i n$ is $/ \mathbf{z i}^{341 /}$ (cf. Pingwu Baima $/ \mathbf{z y}^{341} /$, WT yod). The form $/ \mathbf{z i}^{341} /$ occasionally occurs as an egophoric (equational/attributive) copula in traditional stories, as in $/ \mathrm{k}^{\mathrm{h}} \mathbf{u}^{53} \mathrm{ndo}^{33} \mathrm{mbu}^{53} \mathrm{zi}^{341} /$ 'I am fat.' (where $/ \mathrm{k}^{\mathrm{h}} \mathbf{u}^{53}$ / is a logophoric pronoun). The default equational copula in the spoken language is $/ \mathrm{re}^{213} /$, as in $/ \mathrm{ga}^{35} 1 \jmath^{33} \mathrm{pe}^{35} \mathrm{re}^{213}, \mathrm{wu}^{33} \mathrm{le}^{53} 6 \mathrm{O}^{33} \mathrm{~s}^{53}$ $\mathrm{re}^{213}$ / 'I am a teacher, he is a student.' (/ $6 \mathrm{O}^{33} \mathrm{~S}^{53} /$ is a loanword from Mandarin Chinese, 学生 xuésheng). The prospective egophoric marker $/ i^{53} /$ may be cognate to the prospective marker kyis (or one of its allomorphs, gyis, gis, 'is or s) (cf. Nagano 1995; Häsler 1999: 168, 184-186).
} 
(3) $\mathrm{S}^{\mathrm{h}} \mathrm{u}^{213} \quad \mathrm{nd} \varepsilon^{53} \quad \mathrm{nd}_{3} \mathrm{a}^{53} \quad \mathrm{t}^{\mathrm{h}} \mathrm{a}^{53} \mathrm{Hy}^{341}$
mushroom this $\quad$ eat.N-PST EXP.EGO
'I have eaten this type of mushrooms (in the past).'

(ii) with second person subjects in direct questions. This use conforms to the "anticipation rule" in Tibetic languages, whereby the speaker anticipates the access/source available to the hearer and selects the evidential marker accordingly (Tournadre and LaPolla 2014: 245). Consider the following examples:

(4) $t 6^{\mathrm{h}} \varnothing^{53} \quad \mathrm{ndu}^{35} \quad \mathrm{ia}^{53}$ ?

2SG drink PRSP.EGO.Q

'Will you drink?'

(5) $\mathrm{t}^{\mathrm{h}} \varnothing^{53} \quad \mathrm{sj}^{35} \quad \mathrm{ndu}^{35} \quad \mathrm{mbJ}^{33} \quad \mathrm{ua}^{33}$ ?

2SG food drink CMPL PFV.EGO.INT.Q

'Have you eaten?'

Non-egophoric markers are used:

(i) with non-first person subjects in statements and third-person subjects in questions, as in the following examples:

(6a) $\mathrm{t}^{\mathrm{h}} \emptyset^{53} / \mathrm{k}^{\mathrm{h}} \mathrm{u}^{33} \mathrm{ji}^{53} \quad \mathrm{nj}^{53} \quad \mathrm{re}^{213}$.

2SG/3SG buy.N-PST PRSP.N-EGO

'You / he will (definitely) buy (it).'

(6b) $\mathrm{t}^{\mathrm{h}} \emptyset^{53} / \mathrm{k}^{\mathrm{h}} \mathrm{u}^{33} \mathrm{ji}^{53} \quad \mathrm{nd} \mathrm{ii}^{53} \quad \mathrm{re}^{213}$.

2SG/3SG walk.N-PST PRSP.N-EGO

'You / he will (definitely) walk.' 
(7)

$\mathrm{t}^{\mathrm{h}} \emptyset^{53} / \mathrm{k}^{\mathrm{h}} \mathrm{u}^{33} \mathrm{ni}^{53} \quad \mathrm{j} \varepsilon^{35} \quad \mathrm{n}^{213}$.

2SG/3SG sleep DUR.N-EGO

'You are / he is sleeping.'

(8) $\mathrm{S}^{\mathrm{h}} \mathrm{u}^{213} \quad \mathrm{nd} \varepsilon^{53} \quad \mathrm{k}^{\mathrm{h}} \mathrm{u}^{33} \mathrm{ji}^{53} \quad \mathrm{nd}_{3} \mathrm{a}^{53} \quad \mathrm{t} \int^{\mathrm{h}} \mathrm{a}^{53} \mathrm{n} \jmath^{213}$.

mushroom this $3 \mathrm{SG} \quad$ eat.N-PST EXP.N-EGO

'He has eaten this type of mushrooms (in the past).'

(9)

$\begin{array}{llllll}\mathrm{S}^{\mathrm{h}} \mathrm{u}^{213} & \mathrm{nd} \varepsilon^{53} & \mathrm{k}^{\mathrm{h}} \mathrm{u}^{33} \mathrm{ni}^{53} & \mathrm{nd}_{3 \mathrm{a}^{53}} & \mathrm{t} \int^{\mathrm{h}} \mathrm{a}^{53} \mathrm{~nJ}^{213} & \mathrm{a}^{33} ? \\ \text { mushroom } & \text { this } & 3 \mathrm{SG} & \text { eat.N-PST } & \text { EXP.N-EGO } & \mathrm{Q}\end{array}$

'Has he ever eaten that type of mushrooms?'

(ii) with first person subjects in statements, referring to internal (or endopathic) states, such as cold, pain, hunger, or fear, over which the subject does not have control (e.g. Tournadre and Dorje 2003: 167; Tournadre and LaPolla 2014: 242). Examples include:

$$
\begin{aligned}
& \mathrm{ya}^{35} \quad \mathrm{k}^{\mathrm{h}} \mathbf{i}^{35} \quad \mathrm{re}^{213} . \\
& \text { 1SG be.sick } \quad \text { PRSP.N-EGO } \\
& \text { '(If it continues like that) I will certainly fall ill.' }
\end{aligned}
$$

The system of evidentials allows for interchangeability between the markers so that the speaker is free to choose different markers to signal the degree of his involvement into the situation under description. Not only can first person subjects co-occur with non-egophoric markers (as in the case of endopathic verbs), but non-first person subjects can also co-occur with egophoric markers. The latter use implies that the speaker is responsible for conceptualizing or observing the reported situation and committed to its truthfulness. ${ }^{7}$ Consider the following examples:

\footnotetext{
${ }^{7}$ Such use can also be analyzed in terms of empathy, "the speaker's identification, which may vary in degree, with a person/thing that participates in the event or state that he describes in a sentence" (Kuno 1987: 206). By taking the third person actor's viewpoint, the speaker signals her certainty about the person's actions (cf. Häsler's 1999, 2001 analysis of evidentials in Sde-dge Tibetan).
} 
(11)

$k^{\mathrm{h}} \mathrm{u}^{33} \mathrm{ni}^{53} \quad \mathrm{nd}_{3} \mathrm{a}^{53} \quad \mathrm{i}^{53}$.

3SG eat.N-PST PRSP.N-EGO

'(I know that) he will definitely eat.'

(12)

$\mathrm{k}^{\mathrm{h}} \mathrm{u}^{33} \mathrm{ni}^{53} \quad \mathrm{sj}^{35} \quad \mathrm{ndu}^{35} \quad \mathrm{mb}^{33} \quad \mathrm{ua}^{33} ?$

3SG food drink COMPL PFV.EGO.INT.Q

'(Do you know whether) he has eaten?'

Evidential markers that co-occur with past verb stems enrich the basic organization of the system by some additional meanings. Notable is also the complex system of oppositions whereby one and the same marker may stand in contrast to several markers depending on the type of verb, with which it combines, and the person of the subject.

(i) $/ \mathrm{t}^{\mathrm{h}} \mathcal{E}^{33} /$ contrasts to $/ \mathrm{s}^{33} /$ in specifying the source of information: direct vs. indirect, respectively.

When used with volitional (or controllable) verbs and non-first person subjects, ${ }^{8}$ $/ \mathrm{t}^{\mathrm{h}} \mathcal{E}^{33} /$ signals that the speaker witnessed the event under description. By contrast, $/ \mathrm{s}^{33} /$ indicates that the reported event is not directly witnessed by the speaker, but deduced on the basis of available physical evidence. Compare the following sentences:

$$
\mathrm{k}^{\mathrm{h}} \mathrm{a}^{33} \mathrm{r}^{33}-\mathrm{ku}^{53} \quad \mathrm{ss}^{35} \quad \mathrm{ndu}^{35} \quad \mathrm{mb}^{33} \quad \mathrm{t}^{\mathrm{h}} \varepsilon^{33} .
$$

3-PL food drink COMPL DIR

'(I saw that) they have eaten.'

(14)

$\mathrm{k}^{\mathrm{h}} \mathrm{a}^{33} \mathrm{r}^{33}-\mathrm{ku}^{53} \quad \mathrm{s \jmath ^{35 }} \quad \mathrm{ndu}^{35} \quad \mathrm{mbJ}^{33} \quad \mathrm{~S}^{33}$.

3-PL food drink COMPL PFV

'They have eaten.' (inferred, e.g. by empty plates on the table)

\footnotetext{
${ }^{8}$ Volitional or controllable verbs refer to those actions and behaviors that the speaker is able to control through her subjective will, such as 'go', 'eat', or 'look'.
} 
When used with endopathic verbs, the direct evidential $/ \mathrm{t} \epsilon^{\mathrm{h}} \varepsilon^{33} /$ is generally used to refer to the speaker's own internal state, whereas $/ \mathrm{s}^{33} /$ is used to report internal states of others (but see also (iv) below). Compare the following sentences:

$$
\mathrm{ya}^{35} \quad \mathrm{k}^{\mathrm{h}} \mathrm{i}^{35} \quad \mathrm{t} 6^{\mathrm{h}} \mathcal{\varepsilon}^{35}
$$

1SG be.sick DIR

'I fell ill.'

(16)

$\begin{array}{llll}\mathrm{k}^{\mathrm{h}} \mathrm{u}^{33} \mathrm{ni}^{53} & \mathrm{k}^{\mathrm{h}} \mathbf{i}^{35} & \mathrm{mbj}^{33} & \mathrm{~S}^{33} . \\ 3 \mathrm{SG} & \text { be.sick } & \text { COMPL } & \text { PFV }\end{array}$

'He has fallen ill.'

(ii) $/ \mathrm{t}^{\mathrm{h}} \mathcal{\varepsilon}^{33} /$ contrasts to $/ 6 \mathrm{y}^{35} /$ in specifying the direction of motion.

In addition to being evidential markers, $/ \mathrm{t} \epsilon^{\mathrm{h}} \mathcal{E}^{33} /$ and $/ \varphi \mathrm{y}^{35} /$ are also full-fledged verbs of motion: $/ \mathrm{t}^{\mathrm{h}} \mathcal{E}^{33} /$ is the past form of the verb ' $\mathrm{go}$ ', whereas $/ 6 \mathrm{y}^{35} /$ is the past form of the verb 'come, appear'. Examples include:

$\mathrm{di}^{35} \quad \mathrm{ka}^{35} \quad \mathrm{t}^{\mathrm{h}} \mathcal{\varepsilon}^{35} \quad \mathrm{dz}^{35} ? \quad \mathrm{di}^{35} \quad \mathrm{ji}^{53} \quad \mathrm{se}^{53} \quad \mathrm{t}^{\mathrm{h}} \mathcal{\varepsilon}^{35}$

demon where go.PST say.PST demon person kill go.PST

، "Where did the demon go?" he asked, "The demon went to kill humans".'

(18)

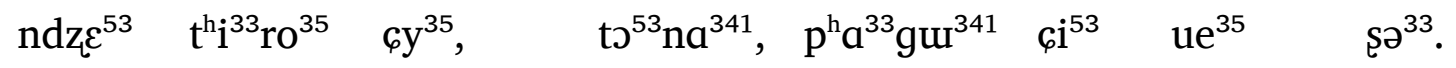
demon ghost appear.PST bear wild.pig home come.PST PFV 'Demons and ghosts appeared, bears and wild pigs came home.'

One difference between $/ \mathrm{t} \epsilon^{\mathrm{h}} \varepsilon^{33} /$ and $/ 6 \mathrm{y}^{35} /$ as verbs of motion is that the former can be used as a finite verb co-occurring with evidential markers (as in 19), whereas the latter cannot. Finite forms of the verb 'come' make use of the past stem /ue $\mathrm{e}^{35}$ ( (as in example 18). 
$\mathrm{t} 6^{\mathrm{h}} \mathrm{y}^{53} \quad \mathrm{t} \int^{\mathrm{h}} \partial^{53} \quad \mathrm{zo}^{341} \quad \mathrm{t} 6^{\mathrm{h}} \varepsilon^{35} \quad \mathrm{u} \varepsilon^{33} ?$

2SG what make.N-PST go.PST PFV.EGO.INT

'Where have you been up to? [lit. What did you go to do?]'

Both $/ \mathrm{t} \varphi^{\mathrm{h}} \varepsilon^{33} /$ and $/ \mathrm{cy} /$ are also used with verbs of motion as auxiliaries indicating the direction of motion in relation to the speaker. Compare the following sentences:

$\begin{array}{llllll}\mathrm{k}^{\mathrm{h}} \mathrm{u}^{33} \mathrm{ni}^{53} & \mathrm{tse}^{53} & \mathrm{t}^{\mathrm{h}} \mathcal{\varepsilon}^{35} . & \mathrm{k}^{\mathrm{h}} \mathrm{u}^{33} \mathrm{ji}^{53} & \mathrm{tse}^{53} & 6 \mathrm{y}^{35} . \\ \text { 3SG } & \text { arrive } & \text { go.PST } & \text { 3SG } & \text { arrive } & \text { appear.PST }\end{array}$

'He arrived (there, some place away from the speaker). He arrived (here, towards the speaker).'

(iii) $/ 6 \mathrm{y}^{35} /$ contrasts to $/ \mathrm{u} \varepsilon^{33} /$ in specifying the speaker as the voluntary or involuntary participant of the event.

In addition to denoting the actual direction of movement towards the speaker with verbs of motion, $/ 6 \mathrm{y}^{35} /$ can be used with non-motion verbs to indicate that the action is directed towards the speaker metaphorically. In such cases, $/ 6 \mathrm{y}^{35} /$ indicates that the speakersubject has undergone the action involuntarily. In this function, Baima $/ 6 \mathrm{y}^{35} /$ appears a close counterpart of the auxiliary byung in Standard Tibetan (cf. Tournadre and Dorje 2003: 169). Examples include:

$$
\begin{array}{lllllll}
\mathrm{ya}^{35} & \mathrm{jJ}^{35} & \mathrm{ci}^{53} & \mathrm{ue}^{35} & \mathrm{t} \int^{\mathrm{h}} \mathrm{a}^{33} \mathrm{pa}^{53} & \mathrm{pu}^{35} & 6 \mathrm{y}^{35} . \\
1 \mathrm{SG} & \text { just } & \text { home } & \text { come.PST } & \text { rain } & \text { fall.PST } & \text { EGO.RCP }
\end{array}
$$

'Just as I came home it started raining.'

$$
\begin{aligned}
& \mathrm{t} \int^{\mathrm{h} \partial^{53}} \mathrm{i}^{33} \mathrm{ggi}^{53} \quad \mathrm{ly}^{35} \quad 6 \mathrm{y}^{35} . \\
& \text { what matter happen } \text { EGO.RCP } \\
& \text { 'What happened (to you)?' }
\end{aligned}
$$


In neat contrast to $/ 6 \mathrm{y}^{35} /, / \mathrm{u}^{33} /$ indicates that the speaker is the willful instigator of a situation, as in the following sentence:

$\begin{array}{lllll}\text { ya }^{35} & \text { s }^{35} & \mathrm{ndu}^{35} & \mathrm{mbj}^{33} & \mathrm{u} \varepsilon^{33} \\ \text { 1SG } & \text { food } & \text { drink } & \text { COMPL } & \text { PFV.EGO.INT }\end{array}$

'I have eaten.'

(24) $\mathrm{ya}^{53} \quad \mathrm{se}^{53} \quad \mathrm{mbJ}^{33} \quad \mathrm{u}^{33}$.

fox kill COMPL PFV.EGO.INT

'I killed the fox.'

$/ \mathrm{u}^{33} /$ is also accepted in sentences with endopathic verbs, where it stands to imply, albeit idiosyncratically, that the speaker voluntarily incurred some internal state, e.g.:

$$
\begin{aligned}
& \mathrm{ya}^{35} \quad \mathrm{k}^{\mathrm{h}} \mathbf{i}^{35} \quad \mathrm{mb}^{33} \quad \mathrm{u}^{33} \text {. } \\
& \text { 1SG be.sick COMPL PFV.EGO.INT } \\
& \text { 'I have (purposely) fell ill.' }
\end{aligned}
$$

While possible grammatically, such use is, of course, pragmatically implausible, and is generally met with laughter from native speakers.

(iv) $/ \mathrm{s} \partial^{33} /$ can be used a factual counterpart of $/ \mathrm{u} \varepsilon^{33} /$ and $/ \mathrm{t} \varphi^{\mathrm{h}} \varepsilon^{35} /$.

Similar to $/ \mathrm{u}^{33} /, / \mathrm{S}^{33} /$ can be used with first person subjects and endopathic verbs.

\begin{tabular}{|c|c|c|c|}
\hline (26) $\mathrm{k}^{\mathrm{h}} \mathrm{u}^{53}$ & $\mathrm{k}^{\mathrm{h}} \mathrm{\jmath}^{53}$ & $\mathrm{mbj}^{33}$ & $\mathrm{t} \varphi^{\mathrm{h}} \varepsilon^{35}$ \\
\hline LOG & lose & COMPL & DIR \\
\hline
\end{tabular}
Compare the following two sentences cited from one and the same traditional story and describing one and the same event: 
$\begin{array}{llll}k^{h} u^{53} & k^{h} \partial^{53} & m^{3} \partial^{33} & S \partial^{33}\end{array}$

LOG lose COMPL PFV

'I lost (the competition).'

The use of the direct evidential $/ \mathrm{t} \epsilon^{\mathrm{h}} \varepsilon^{35} /$ in sentence (26) puts an emphasis on the source of information (sensory channels). The use of $/ \mathrm{S}^{33} /$ in sentence (27), on the other hand, represents a factual account of the reported situation.

$/ \mathrm{S}^{33} /$ is also the default perfective marker used with first person subjects and verbs of motion, as in the following example:

$$
\begin{array}{lll}
\mathrm{ya}^{35} & \mathrm{tse}^{53} & \mathrm{Sə}^{33} \\
1 \mathrm{SG} & \text { arrive } & \mathrm{PFV}
\end{array}
$$

'I arrived.'

The distribution of Pingwu Baima past evidential markers in relation to the type of verbs and the person of the subject is summarized in Table 3.

Table 3: Distribution of Pingwu Baima past evidential markers in relation to the type of verbs

\begin{tabular}{|c|c|c|c|c|}
\hline & \multicolumn{2}{|c|}{ First person subject } & \multicolumn{2}{|c|}{ Non-first person subject } \\
\hline & $\begin{array}{l}\text { egophoric } \\
\text { intentional }\end{array}$ & $\begin{array}{l}\text { egophoric } \\
\text { receptive }\end{array}$ & direct & inferred/factual \\
\hline $\begin{array}{l}\text { volitional } \\
\text { verbs }\end{array}$ & $\mathrm{u} \varepsilon^{33}$ & $6 y^{35}$ & $\mathrm{t} 6^{\mathrm{h}} \varepsilon^{35}$ & \multirow{3}{*}{$s \partial^{33}$} \\
\hline $\begin{array}{l}\text { endopathic } \\
\text { verbs }\end{array}$ & & $\begin{array}{l}\mathrm{t} \epsilon^{\mathrm{h}} \varepsilon^{35} \text { (sensory source of } \\
\text { information) } \\
\mathrm{s}^{33} \text { (factual account) }\end{array}$ & $s \partial^{33}$ & \\
\hline $\begin{array}{l}\text { motion } \\
\text { verbs }\end{array}$ & $S \partial^{33}$ & $\begin{array}{c}6 \mathrm{y}^{35} \text { (centripet } \\
\mathrm{t} \varphi^{\mathrm{h}} \varepsilon^{35} \text { (centrifu }\end{array}$ & & \\
\hline
\end{tabular}
and the person of the subject 
As shown in Table 3, $/ \mathrm{S}^{33} /$ is the least restricted form, which can co-occur with all types of verbs and all types of subjects. Together with $/ \mathrm{u}^{33} /, / \mathrm{S}^{33} /$ also has high frequency of occurrence in my corpus of traditional stories. $/ 6 \mathrm{y}^{35} /$ and $/ \mathrm{t} \epsilon^{\mathrm{h}} \varepsilon^{35} /$, on the other hand, occur less frequently. They are chiefly used as verbs of motion or auxiliaries indicating the direction of motion. $/ 6 \mathrm{y}^{35} /$ is more restricted in distribution that $/ \mathrm{t} \epsilon^{\mathrm{h}} \varepsilon^{35} /$, as it is mostly only used with the verb / $\mathrm{tse}^{53} /$ slebs 'arrive', as in the following example:

$\begin{array}{lllllll}\text { to }^{35} & \mathrm{ta}^{33} \mathrm{j}^{35} & \mathrm{~d} \mathrm{ga}^{341} \mathrm{k}^{\mathrm{h}} \mathrm{a}^{33} \mathrm{ts}^{\mathrm{h}} \partial^{53} & \mathrm{~s}^{33} & \mathrm{na}^{53} & \mathrm{tse}^{53} & 6 \mathrm{y}^{35} . \\ \text { on } & \text { just.now } & \text { beggar } & \text { INDF } & \text { here } & \text { arrive } & \text { appear.PST }\end{array}$

'A beggar just came here.'

$/ 6 \mathrm{y}^{35 /}$ in its function as the egophoric receptive marker is the least frequent of all evidential markers. Its use has been mainly documented through elicitation.

$/ \mathrm{u} \varepsilon^{33} /$ and $/ \mathrm{s}^{33} /$ also stand in clear contrast to $/ \mathrm{t} \varphi^{\mathrm{h}} \varepsilon^{35} /$ and $/ 6 \mathrm{y}^{35} /$ with respect to their degree of grammaticalization. $/ \mathrm{u}^{33} /$ and $/ \mathrm{s}^{33} /$ are etymologically obscure, bound morphs. ${ }^{9}$ $/ \mathrm{t} \varphi^{\mathrm{h}} \mathcal{E}^{35} /$ and $/ \mathrm{cy} /$, on the other hand, exhibit a low degree of grammaticalization. They retain their status of autonomous units (as in examples 17-18) and show no signs of desemanticization, phonological attrition, or loss of morphosyntactic properties (cf. Lehmann 1995: 121-178).

\section{Pingwu Baima evidentials in the Tibetic context}

The system of evidentiality in Pingwu Baima incorporates some very specific categories - such as egophoric, endopathic, and anticipation rule — all of which are held to be characteristic properties of the evidential systems of the Tibetic family (e.g. Tournadre 1996; Tournadre and Konchok Jiatso 2001; Tournadre and LaPolla 2014: 252-256). Overall,

\footnotetext{
${ }^{9}$ Based on the basic grammatical functions of $/ \mathbf{u}^{33} /$ and $/ \mathrm{s}^{33} /$, Huang and Zhang (1995: 108) argue that the former is a contracted form of pa-yin of Standard Tibetan, whereas the latter is a variant of the Proto-Tibetan past tense morpheme ${ }_{-S}$. This is not quite in accord with regular sound correspondences between OT and Baima or with the paradigmatic relationship of these two markers to other members of the evidential system, as discussed in this article. The etymological origins of $/ \mathrm{u} \varepsilon^{33} /$ and $/ \mathrm{S}^{33} /$ are yet to be determined.
} 
evidentiality systems in Tibetic languages are held to be similar in their structure and morphogenesis. When differences occur, they are related to phonological and lexical variation between varieties. A comparative analysis of the final auxiliary verb systems of various Tibetic languages by Nicolas Tournadre also reveals that the range of evidential morphemes across the Tibetic family is limited, while lexical choices in a particular variety can be diagnostic of that variety's group membership (1996; Tournadre and Konchok Jiatso 2001: 82-88).

How does Baima fit into this picture? Table 4 provides Pingwu Baima evidentials together with their function equivalents in various Tibetic languages, including Standard Tibetan, two Khams varieties, and three Amdo varieties (comprising two Tibetic languages of the border areas between southern Gansu and northern Sichuan, Thebo and Mdzo-dge) (based on Tournadre and Konchok Jiatso 2001: 84-87; J. Sun 1993).

Table 4. Evidential markers in Pingwu Baima compared to their function equivalents in various Tibetic languages (adapted from Tournadre and Konchok Jiatso 2001: 84-87; J. Sun 1993)

\begin{tabular}{|c|c|c|c|c|c|c|c|}
\hline \multirow{2}{*}{ Marker } & \multirow{2}{*}{$\begin{array}{l}\text { Pingwu } \\
\text { Baima }\end{array}$} & \multirow{2}{*}{$\begin{array}{c}\text { Ü-Tsang } \\
\text { Lhasa }\end{array}$} & \multicolumn{2}{|c|}{ Khams } & \multicolumn{3}{|c|}{ Amdo } \\
\hline & & & Chunyido & Nakchu & Labrang & Thebo & $\begin{array}{c}\text { Mdzo- } \\
\text { dge }\end{array}$ \\
\hline $\begin{array}{l}\text { Prospective } \\
\text { egophoric }\end{array}$ & $\begin{array}{c}\mathrm{i}^{53} \\
\text { gyis? }\end{array}$ & gi-yin & $\begin{array}{l}\text { fijẽ̃ } \\
\text { gyi-yin }\end{array}$ & $\begin{array}{c}\text { fijẽ̃ } \\
\text { gyi-yin }\end{array}$ & $\begin{array}{c}\tilde{\mathrm{j}} \\
\text { rgyu-yin }\end{array}$ & $\begin{array}{c}\quad \text { i } \\
? \text { rgyu }\end{array}$ & \\
\hline $\begin{array}{l}\text { Prospective } \\
\text { non-egophoric }\end{array}$ & $\begin{array}{c}\mathrm{re}^{213} \\
\text { red }\end{array}$ & gi-red & $\begin{array}{l}\text { lire? } \\
\text { le-red }\end{array}$ & $\begin{array}{l}\text { lere? } \\
\text { le-red }\end{array}$ & $\begin{array}{c}\text { fire? } \\
\text { rgyu-red }\end{array}$ & $\begin{array}{c}\text { ci gi } \\
\text { ? rgyu-'gi }\end{array}$ & \\
\hline $\begin{array}{l}\text { Durative / } \\
\text { Existential } \\
\text { egophoric }\end{array}$ & $\begin{array}{l}\mathrm{zy}^{341} \\
\text { yod }\end{array}$ & gi-yod & $\begin{array}{c}6 \mathrm{u} \\
\text { bzhin-yod }\end{array}$ & $\begin{array}{c}\text { 6ü } \\
\text { ?bzhin- } \\
\text { *'od }\end{array}$ & $\begin{array}{c}\text { go } \\
\text { gi-yod }\end{array}$ & $\begin{array}{c}\text { yije } \\
\text { ?bzhin-yod } \\
\text { /?gi-yod } \\
\end{array}$ & $\begin{array}{l}\text { jod } \\
\text { yod }\end{array}$ \\
\hline $\begin{array}{l}\text { Durative / } \\
\text { Existential } \\
\text { non-egophoric }\end{array}$ & $\begin{array}{l}\mathrm{n} \partial^{213} \\
\text { snang }\end{array}$ & $\begin{array}{l}\text { gi-yod- } \\
\text { red }\end{array}$ & $\begin{array}{c}\text { ciore? } \\
\text { bzhin-yod- } \\
\text { red }\end{array}$ & $\begin{array}{l}\text { lere? } \\
\text { le-red }\end{array}$ & $\begin{array}{l}\text { jokə/gə } \\
\text { *gi-yod- } \\
\text { ni-red }\end{array}$ & $\begin{array}{l}\text { yijelegi } \\
\text { ?*bzhin- } \\
\text { yod-le-'gi }\end{array}$ & $\begin{array}{l}\text { jod h } \mathrm{k} \partial \\
\text { ?yod-'gi }\end{array}$ \\
\hline $\begin{array}{l}\text { Egophoric } \\
\text { experiential }\end{array}$ & $\begin{array}{c}\mathrm{t} \int^{\mathrm{h}} \mathrm{a}^{53} \mathrm{zy}^{341} \\
\text { cha yod }\end{array}$ & myong & $\begin{array}{c}\text { nay } \\
\text { myong }\end{array}$ & $\begin{array}{c}\text { ñ̃̃ } \\
\text { myong }\end{array}$ & $\begin{array}{l}\text { jก̃ท } \\
\text { myong }\end{array}$ & $\begin{array}{c}\mathrm{nu} \\
\text { myong } \\
\text { myong }\end{array}$ & $\begin{array}{l}\text { noy } \\
\text { myong }\end{array}$ \\
\hline $\begin{array}{l}\text { Perfective } \\
\text { egophoric } \\
\text { intentional }\end{array}$ & $\begin{array}{c}\mathrm{u} \varepsilon^{33} \\
?\end{array}$ & pa-yin & $\begin{array}{l}\text { lejên } \\
l e-y i n\end{array}$ & $\begin{array}{l}\text { lejin } \\
l e-y i n\end{array}$ & $\begin{array}{c}\text { ni/nəjən } \\
\text { ni-yin }\end{array}$ & $\begin{array}{c}\text { pu le } \\
?\end{array}$ & $\begin{array}{l}(\text { nə) })^{10} \\
\text { ?ni-yin }\end{array}$ \\
\hline
\end{tabular}

\footnotetext{
${ }^{10}$ Jackson Sun (1993: 958) analyzes the enclitic /nə/ as "nothing more than a slot-filler with minimal semantic content or pragmatic function, serving merely to add phonological bulk to monosyllabic predicators." This is quite different from Pingwu Baima, where $/ \mathrm{u}^{33} /$ has a clear function of an evidential.
} 


\begin{tabular}{|c|c|c|c|c|c|c|c|}
\hline $\begin{array}{l}\text { Direct } \\
\text { (centrifugal) }\end{array}$ & $\begin{array}{l}\mathrm{t}^{\mathrm{h}} \varepsilon^{35} \\
\text { chas }\end{array}$ & song & $\begin{array}{l}\mathrm{t}^{\mathrm{h}} \mathrm{en} \\
\text { thal }\end{array}$ & $\begin{array}{c}\mathrm{t}^{\mathrm{h}} \mathrm{i} \\
\text { thal }\end{array}$ & $\begin{array}{l}\mathrm{t}^{\mathrm{h}} \mathrm{a} \\
\text { thal }\end{array}$ & $\begin{array}{l}\mathrm{t}^{\mathrm{h}} \mathrm{j} \varepsilon \\
\text { thal }\end{array}$ & $\begin{array}{l}\mathrm{t}^{\mathrm{h}} æ \\
\text { thal }\end{array}$ \\
\hline $\begin{array}{l}\text { Perfective } \\
\text { egophoric } \\
\text { receptive } \\
\text { (centripetal) }\end{array}$ & $\begin{array}{c}6 \mathrm{y}^{35} \\
\text { byung }\end{array}$ & byung & $\begin{array}{l}? \\
?\end{array}$ & $\begin{array}{l}\text { tcũ̃n } \\
\text { byung }\end{array}$ & $\begin{array}{l}\mathrm{t}^{\mathrm{h}} \mathrm{a} \\
\text { thal }\end{array}$ & $\begin{array}{l}\mathrm{t}^{\mathrm{h}} \mathrm{j} \varepsilon \\
\text { thal }\end{array}$ & \\
\hline Indirect & $\begin{array}{c}s \partial^{33} \\
?\end{array}$ & bzhag & $\begin{array}{c}\text { cəda } \\
\text { bzhag-gda' }\end{array}$ & $\begin{array}{c}\text { cuyda } \\
\text { ?bzhag- } \\
g d a^{\prime}\end{array}$ & $\begin{array}{c}\text { tãnzək/ } \\
\text { zogə } \\
\text { dang-zug }\end{array}$ & $\begin{array}{c}\text { puci } \\
?\end{array}$ & $\begin{array}{c}\text { zəg } \\
\text { ?zəg } \\
\text { indefinite } \\
\text { marker }\end{array}$ \\
\hline Factual & $\begin{array}{c}\mathrm{s}{ }^{33} \\
?\end{array}$ & pa-red & $\begin{array}{l}\text { lere? } \\
\text { le-red }\end{array}$ & $\begin{array}{l}\text { lere? } \\
\text { gi-red }\end{array}$ & $\begin{array}{l}\text { nore? } \\
\text { ni-red }\end{array}$ & $\begin{array}{l}\text { le gi } \\
* l e-' g i\end{array}$ & $\begin{array}{l}\text { nə re } \\
\text { ni-red }\end{array}$ \\
\hline
\end{tabular}

The comparative data in Table 4 suggest that the Pingwu Baima system may combine features of different groups of Tibetic languages. On the one hand, Pingwu Baima is similar to Central and Khams varieties in marking a distinction between centrifugal and centripetal evidentials and sharing the receptive egophoric marker byung. Interestingly, in Pingwu Baima, these are the markers that are but little grammaticalized and relatively marginal (especially $/ 6 \mathrm{y}^{35} /$ ). For that reason, they are possibly recent additions to the Pingwu Baima system. On the other hand, Pingwu Baima may share some irregular developments with the Tibetic varieties spoken in its neighborhood, at the border of Sichuan and Gansu provinces. One such development is a possible link between the indirect evidential marker and the indefinite marker in Mdzo-dge Tibetan (both /zəg/). That is parallel in Pingwu Baima, where the indirect and factual marker $/ \mathrm{s}^{33} /$ is homophonous with the indefinite marker $/ \mathrm{s}^{33} /$ (as in example 29). In his analysis of Mdzo-dge, J. Sun (1993: 953) proposes a cross-linguistically infrequent grammaticalization path from the indefinite marker to the indirect evidential via the semantic extension referential indefiniteness $>$ evidential indirectness. In contrast to the centrifugal-centripetal distinction shared with Central and Khams varieties, that feature that is common between Pingwu Baima and Mdzo-dge relates to the etymologically obscure, highfrequency marker $/ \mathrm{S}^{33} /$, which is therefore likely to belong to the core layer of the evidentialaspectual system of Baima. If discovered in other Tibetic languages of northern Sichuan and southern Gansu, the unusual development from the indefinite marker to the indirect evidential marker may be taken as evidence of close historical relationship between these varieties, supporting the Eastern grouping of Tibetic languages. Naturally, more work is required to 
arrive at a more complete view of Baima, Tibetic varieties in its neighbourhood and their relationship to each other.

Overall, the system of evidentiality in Pingwu Baima appears quite dissimilar to other Tibetic languages in its lexical choices, etymological origins and morphology (note the lack in Pingwu Baima of any nominalizing or connective morphemes commonly attached to verb stems in other Tibetic languages). Whether an idiosyncratic development, a product of competing contact processes, or (most likely) a combination of the two, the system of evidentiality in Pingwu Baima stands out as fairly unique in the Tibetic context, nicely illustrating the diversity of evidential systems among Tibetic languages.

\section{References}

Chirkova, Katia. 2007. Between Tibetan and Chinese: Identity and language in Chinese South-West. Journal of South Asian Studies 30(3). 405-417.

Chirkova, Katia. 2008a. Baimayu shizheng fanchou ji qi yu Zangyu fangyan de bijiao 白马语 示证范畴及其与藏语方言的比较 [Evidentials in Baima and Tibetan dialects compared]. Minzu Yuwen 《民族语文》 [Minority Languages of China] 3. 36-43.

Chirkova, Katia. 2008b. On the position of Baima within Tibetan: A look from basic vocabulary. In Alexander Lubotsky, Jos Schaeken, and Jeroen Wiedenhof (eds.), Evidence and counter-evidence: Festschrift for F. Kortland, Volume 2: General linguistics, 69-91. Amsterdam: Rodopi.

Chirkova, Katia. 2008c. Baima Zangzu wei Dizu shuo zhiyi 白马藏族为氏族说质疑 [The Baima Tibetans and the Di People of Chinese Historical Records: Challenging the Link]. Bulletin of Chinese Linguistics 3(1). 167-180.

Häsler, Katrin Louise. 1999. A Grammar of the Tibetan Sde.dge Dialect. Berne: Berne University dissertation.

Häsler, Katrin Louise. 2001. An empathy-based approach to the description of the verb system of the Dege dialect of Tibetan. Linguistics of the Tibeto-Burman Area 24(1). 134.

Hill, Nathan W. 2013. Come as lord of the black-headed: an Old Tibetan mythic formula. In Christoph Cüppers, Robert Mayer, and Michael Walter (eds.), Tibet after empire: Culture, society and religion between 850-1000, 169-179. Lumbini: Lumbini International Research Institute.

Huang Bufan 黄布凡 and Zhang Minghui 张明慧. 1995. Baima zhishu wenti yanjiu 白马话 支属问题研究 [A study of the genetic affiliation of Baima]. Zhongguo Zangxue 《中国 藏学》 [Tibetology in China] 2. 79-118.

Huang Bufan 黃布凡, Xu Shouchun 许寿椿, Chen Jiaying 陈嘉瑛, and Wang Huiyin 王会 银 (eds.). 1992. Zang-Mian yuzu yuyan cihui 《藏缅语族语言词汇》 [A TibetoBurman lexicon]. Beijing: Zhongyang Minzu Daxue 中央民族大学出版社.

Jacques, Guillaume. 2014. Cone. In Jackson T.-S. Sun (ed.), Phonological profiles of littlestudied Tibetic varieties (Language and Linguistics Monograph Series 55), 269-375. Taipei: Academia Sinica, Institute of Linguistics.

Kuno, Susumu. 1987. Functional syntax: Anaphora, discourse and empathy. Chicago: The University of Chicago Press. 
Lehmann, Christian. 1995. Thoughts on grammaticalization (LINCOM Studies in Theoretical Linguistics 01). München \& Newcastle: Lincom Europa.

Lin, You-Jing. 2014. Thebo. In Jackson T.-S. Sun (ed.), Phonological profiles of littlestudied Tibetic varieties (Language and Linguistics Monograph Series 55), 215-267. Taipei: Academia Sinica, Institute of Linguistics.

Nagano, Yuhiko. 1995. Function of Written Tibetan instrumental particle, -kyis, revisited. In Nishi Yoshio, James A. Matisoff, Yasuhiko Nagano (eds.), New horizons in TibetoBurman morphosyntax, 133-142. Osaka: National Museum of Ethnography.

Nishida, Tatsuo 西田龙雄 and Sun Hongkai 孙宏开. 1990. Hakuba yakugo no kenkyü: Hakuba no kōzō to keitō 《白馬譯語の研究: 白馬語の构造と系统》 [A study of the Baima-Chinese vocabulary 'Baima yiyu': the structure and affiliation of the Baima language]. Kyoto 京都: Shokado 松香堂.

Sun, Hongkai 孙宏开. 1980a. Baima ren de yuyan 白马人的语言 [The language of the Baima people]. In Sichuan Institute of Minority Nationalities 四川民族研究所编 (eds.), Baima Zangzu renshu wenti taolunji 《白马藏人族属问题讨论集》 [Genetic affiliation of Baima Tibetans], 15-25. Chengdu: Sichuan Institute of Minority Nationalities 四川民族 研究所.

Sun, Hongkai 孙宏开. 1980b. Lishi shang de Dizu he Chuan Gan diqu de Baima ren 历史上 的氏族和川甘地区的白马人 [The Di people of historical records and the Baima people of Sichuan and Gansu]. Minzu Yanjiu 《民族研究》 [Nationalities Studies] 3. $33-43$.

Sun, Hongkai 孙宏开. 2003. Baimayu shi Zangyu de yige fangyan huo tuyu ma? 白马语是 藏语的一个方言或土语吗? [Is Baima a dialect or vernacular of Tibetan?]. Yuyan Kexue 《语言科学》[Linguistic Sciences] 1(2). 65-75.

Sun Hongkai 孙宏开, Katia Chirkova 齐卡佳, and Liu Guangkun 刘光坤. 2007. Baima yu yanjiu 《白马语研究》 [A study of the Baima language]. Beijing: Minzu Chubanshe.

Sun, Jackson T.-S. 1993. Evidentials in Amdo Tibetan. Bulletin of the Institute of History and Philology 《中央研究院历史语言研究所集刊》63(4). 945-1001.

Sun, Jackson T.-S. 2003a. Qiuji Zangyu de yuyin tezheng 求吉藏语的语音特征 [Phonological characteristics of Chos-rje Tibetan]. Minzu Yuwen 《民族语文》 [Minority Languages of China] 6.1-6.

Sun, Jackson T.-S. 2003b. Phonological profile of Zhongu: a new Tibetan dialect of Northern Sichuan. Language and Linguistics 4(4). 769-836.

Tournadre, Nicolas. 1996. Comparaison des systèmes médiatifs de quatre dialectes tibétains (tibétain central, ladakhi, dzongkha et amdo). In Zlatka Guentcheva (ed.), L'énonciation médiatisé, 195-213. Louvain: Peeters.

Tournadre, Nicolas. 2014. The Tibetic languages and their classification. In Thomas OwenSmith and Nathan W. Hill (eds.), Trans-Himalayan linguistics: Historical and descriptive linguistics of the Himalayan area (Trends in Linguistics Studies and Monographs Vol. 266), 105-129. Berlin: Mouton de Gruyter.

Tournadre, Nicolas and Konchok Jiatso. 2001. Final auxiliary verbs in literary Tibetan and in the dialects. Linguistics of the Tibeto-Burman Area 24.1: 49-111.

Tournadre, Nicolas and Sangda Dorje. 2003. Manual of Standard Tibetan: Language and civilization. Ithaca, New York: Snow Lion Publications.

Tournadre, Nicolas and Randy J. LaPolla. 2014. Towards a new approach to evidentiality: Issues and directions for research. Linguistics of the Tibeto-Burman Area 37(2). 240263. 
Zhang, Jichuan 张济川. 1994a. Baimahua yu Zangyu, shang 白马话与藏语（上） [Baima and Tibetan, Part 1]. Minzu Yuwen 《民族语文》[Minority Languages of China] 2. 11-24.

Zhang, Jichuan 张济川. 1994b. Baimahua yu Zangyu, xia 白马话与藏语（下）[Baima and Tibetan, Part 1]. Minzu Yuwen 《民族语文》 [Minority Languages of China] 3. 58-67. Zhang, Jichuan. 1997. Particularités phonetiqués du baima. Cahiers de Linguistique Asie Orientale 26(1). 131-153. 